DOI dx.doi.org/10.24866/7444-4707-6/342-354

Л.В. Лысак, Е.В. Лапыгина

\title{
ХАРАКТЕРИСТИКА МИКРОБНЫХ СООБЩЕСТВ ГОРОДСКИХ ПОЧВ ГОРОДА МОСКВЫ
}

Почвы представляют собой неотъемлемый компонент городской среды и существенно отличаются от зональных (фоновых) почв по ряду химических, физических и биологических свойств. Это отражается на выполнении городскими почвами таких важных экологических функций, как сохранение микробного разнообразия, способность почвы к самоочищению от патогенных микроорганизмов, участие в поглощении и выделении парниковых газов и многих других [Почва, город, экология, 1997]. Реализация экологических функций почвы тесно связана с жизнедеятельностью почвенных микроорганизмов, что в значительной степени обеспечивается стабильным функционированием бактериального сообщества почвы [Звягинцев и др., 2005; Степанов и др., 2011].

Целью нашего работы была характеристика обилия и разнообразия микробных сообществ, а также биологической активности городских загрязненных почв Московского региона, сформированных под влиянием разнотипного и разновременного антропогенного воздействия с использованием современных методов почвенной микробиологии.

Исследовали урбаноземы (Urbic technosol) придорожных территорий (загрязнение бензапиреном, тяжелыми металлами), отобранные на территории г. Москвы вблизи автомагистралей и интруземы (Urbic technosol toxic) на территории нефтебазы в районе Капотни (загрязнение нефтепродуктами). Отбор образцов из верхнего горизонта проводился в период времени с 2010 по 2016 гг. в разные сезоны года (весна, лето, осень). Анализировали также образцы основных генетических горизонтов рекреазема (Urbic technosol thaptohumic) и культурозема (Urbic technosol pantohumic) на территории Ботанического сада МГУ (Москва, Ленинские горы) и Филиала Ботанического сада МГУ («Аптекарский огород», Москва, проспект Мира). Подробная характеристика свойств почв приведена в работах [Раппопорт и др., 2001; Строганова и др., 2005; Розанова и др., 2016]. 
Показатели общей численности бактерий, а также численность и содержание фильтрующихся форм (ФФ) бактерий определяли с помощью прямого люминесцентного метода (окраска акридином оранжевым). Численность и жизнеспособность бактерий (долю клеток с неповрежденной клеточной мембраной) определяли при помощи флуоресцентного двухкомпонентного красителя L7012 (LIVE/DEAD BacLight bacterial viability kit.) в соответствии с рекомендациями производителя. Для обнаружения фильтрующихся форм (ФФ) бактерий (ультрамелкие клетки с линейными размерами около 200 нм) использовали разработанный нами метод фильтрации почвенной суспензии через ядерные мембранные фильтры-насадки (Фирма «Sarstedt», размер пор 220 нм) с последующим концентрированием фильтрата центрифугированием [Лысак и др., 2010]. В концентрированных фильтратах почвенной суспензии определяли также численность бактериофагов (фаговых частиц). Определение численности бактериофагов проводили с использованием красителя SYBR Green 1 (Molecular Probes, USA) методом эпифлуоресцентной микроскопии по методике, модифицированной нами для почвенных образцов [Лапыгина и др., 2016]. Морфологическое разнообразие фильтрующихся форм бактерий и бактериофагов изучали при помощи просвечивающей и сканирующей электронной микроскопии [Соина и др., 2012]. Определение численности и таксономической структуры культивируемых бактерий сапротрофного комплекса на родовом уровне проводилось методом посева почвенной суспензии на «универсальную» агаризованную глюкозо-пептонно-дрожжевую среду (ГПД). Идентификацию бактерий до рода проводили на основании фенотипических признаков по ключу для определения почвенных бактерий и общепринятым определителям [Лысак и др., 2003]. Определение интегральных показателей биологической активности городских почв (ферментативная активность, активность азотфиксации, денитрификации, эмиссии диоксида углерода и метана) было проведено с использованием газохроматографических методов [Методы почвенной микробиологии и биохимии, 1991].

Использованный нами метод окраски почвенной суспензии при помощи двухкомпонентного красителя L7012 (LIVE/DEAD) позволяет определить как численность, так и жизнеспособность клеток бактерий. Краситель L7012 дает возможность различить клетки с неповрежденной мембраной, светящиеся при освещении УФ источником света зеленым (“живые”, потенциально жизнеспособные) и клетки с поврежденной мембра- 
ной, светящиеся красным (“мертвые”, потенциально нежизнеспособные) [Лысак, Лапыгина, 2018]. Следует отметить, что показатели численности бактерий, определенные при помощи метода окраски почвенной суспензии акридином оранжевым, традиционно используемым в почвенной микробиологии, были близки к значениям численности бактерий, полученным при окраске L 7012, и составляли от 0.32 до 0.42 млрд. клеток в 1 г почвы. Длительное загрязнение почвы тяжелыми металлами и нефтепродуктами (исследовались городские почвы - урбаноземы и интруземы) не вызывало значительного уменьшения показателей общей численности бактерий, однако несколько сокращало содержание жизнеспособных клеток бактерий по сравнению с ненарушенными природными почвами той же природной зоны. Доля жизнеспособных клеток в загрязненных почвах составляла 55$60 \%$, что меньше, чем в природных ненарушенных почвах, где этот показатель обычно составляет 65-70\% [Лысак, Лапыгина, 2018]. Это свидетельствует о значительной устойчивости и высокой адаптационной способности большей части почвенных бактерий по отношению к действию таких неблагоприятных факторов среды, как высокое содержание тяжелых металлов и нефтепродуктов в почве, что определяется, видимо, защитной ролью почвы по отношению к населяющим ее организмам. Следует отметить определенные преимущества красителя L7012 перед акридином оранжевым, заключающиеся в возможности охарактеризовать как численность, так и состояние (жизнеспособность) бактерий в почве. Это позволяет нам рекомендовать метод окраски почвенной суспензии красителем L7012 в качестве экспресс-метода мониторинга численности и состояния бактериального комплекса как в природных незагрязненных, так и в городских почвах, загрязненных нефтепродуктами и тяжелыми металлами.

С помощью метода электронной микроскопии еще в прошлом веке было показано, что бактерии в почве имеют довольно мелкие размеры. Была высказана гипотеза, что уменьшение размера клеток является одним из механизмов сохранения жизнеспособности бактерий в неблагоприятных условиях природной среды [Дуда и др., 2012]. Методами просвечивающей и сканирующей электронной микроскопии было показано, что мелкие бактерии, описываемые разными авторами терминами “фильтрующиеся формы бактерий”, “ультрамикробактерии”, “наноформы бактерий”, “нанобактерии”, “наннобактерии”, широко распространены в почве и других природных средах [Лысак и др., 2010; Дуда и др., 2012]. 
Это позволило нам предположить, что бактерии в городских загрязненных почвах могут, наряду с более крупными формами, могут быть представлены ФФ бактерий (наноформами бактерий). В городских почвах, загрязненных тяжелыми металлами и углеводородами нефти, численность ФФ бактерий составляла около 50 млн. клеток в 1 г почвы, что сравнимо с их численностью в природных почвах. Это составляло $12-15 \%$ от общего числа клеток бактерий, что в 3 - 10 раз больше, чем в незагрязненных почвах той же природной зоны, где эта величина никогда не превышала 5\% [Лысак и др., 2010]. Высокое содержание ФФ бактерий в городских почвах, загрязненных тяжелыми металлами и углеводородами нефти, свидетельствует в пользу гипотезы о переходе бактерий в состояние ФФ (наноформ) как возможном механизме сохранения жизнеспособности в неблагоприятных условиях среды. Как было показано ранее в наших работах, содержание ФФ бактерий в экстремально холодных местообитаниях (примитивных почвах Антарктиды) также было значительно выше, чем в природных почвах умеренной зоны [Кудинова и др., 2015]. Изучение ФФ бактерий, проведенное при помощи красителя L7012, выявило их высокую жизнеспособность. Содержание жизнеспособных клеток среди ФФ бактерий составляло 85-92\%, что значительно больше доли жизнеспособных клеток среди бактерий обычного размера в загрязненных городских почвах (55-60\%).

Использование метода просвечивающей электронной микроскопии продемонстрировало значительное содержание ФФ бактерий в фильтратах почвенной суспензии городских почв. Были обнаружены два типа клеток. Первый тип характеризовался наличием толстых клеточных стенок, мощной капсулы, S-слоев; второй тип имел обычное строение. Толстая клеточная стенка, капсула, S-слои, мелкие размеры клеток позволяют провести некоторую аналогию с цистоподобными клетками, наблюдавшихся ранее в мерзлотных почвах [Соина и др., 2012]. Можно предположить, что часть клеток, имеющих мелкие размеры, находятся в покоящемся состоянии. Об этом свидетельствует отсутствие у них деления, наличие толстых капсульных слоев, структурное состояние мембраны и цитоплазмы, свойственное покоящимся формам бактерий. Крупные капсулоподобные структуры являются одним из факторов, обеспечивающих устойчивость клеток. Капсулы, как известно, способны защищать клетки микроорганизмов от действия многих неблагоприятных факторов среды. Капсульные слои, очевидно, играют протекторную роль и являются одним 
из факторов, обеспечивающих высокую жизнеспособность ФФ бактерий в условиях воздействия неблагоприятных факторов среды, таких как высокое содержание тяжелых металлов и нефтепродуктов.

В верхнем горизонте урбаноземов (Urbic technosol) придорожных территорий (загрязнение бензапиреном, тяжелыми металлами), отобранные на территории г. Москвы вблизи автомагистралей и интрузема (Urbic technosol toxic) территории нефтебазы в районе Капотни (загрязнение нефтепродуктами) с помощью высокочувствительного красителя SYBR Green 1 была определена также численность бактериофагов. Показатели численности бактериофагов варьировали от 0.5 до 0.8 млрд. в 1 г почвы, что часто превышало численность бактерий, зафиксированную в этих почвах. Обращает на себя внимание, что показатели численности бактериофагов в исследованных городских загрязненных почвах выше, чем их численность в природных ненарушенных почвах той же природной зоны [Лапыгина и др., 2016]. Морфологическое разнообразие бактериофагов довольно велико, в концентрированных фильтратах почвенной суспензии обнаружены следующие морфотипы: хвостатые, икосаэдрические и нитчатые фаги, при этом наиболее часто обнаруживались хвостатые фаги.

Таксономическая структура культивируемых бактерий сапротрофного комплекса в городских загрязненных почвах была изучена при помощи классического метода посева на «универсальную» агаризованную глюкозопептонно-дрожжевую среду, позволяющую выделить из почвы до 50 родов культивируемых аэробных и факультативно-анаэробных бактерий [Лысак и др., 2003]. В урбаноземах с разными типами городских загрязнений бактериальные комплексы имели ряд специфических особенностей и отличались от естественных бактериоценозов ненарушенных почв той же природной зоны. Особого внимания заслуживает изменение структуры бактериального комплекса в сильнозагрязненных городских почвах, проявляющееся в перераспределении таксонов в пользу увеличения удельного веса бактерий, адаптированных к определенному типу загрязнений: пигментированные родококки (род Rhodococcus) - нефтепродукты, полихлорбифенилы; артробактерии (род Arthrobacter), бациллы (род Bacillus) - тяжелые металлы; энтеробактерии (семейство Enterobacteriaceae) - хозяйственно-бытовое загрязнение. Подобные изменения, видимо, следует рассматриваться как индикаторные.

Накопление в городских загрязненных почвах потенциально патогенных (некоторые виды семейства Enterobacteriaceae), а также потенци- 
ально аллергенных бактерий (некоторые виды родов Rhodococcus и Micrococcus), свидетельствует о серьезном нарушении экологической функции почвы как «бактериального фильтра» и может представлять определенную опасность для человека.

Проведенное нами изучение микробных сообществ почв ботанических садов на территории г. Москвы также выявило ряд их особенностей. Эти почвы заслуживают особого внимания почвенных микробиологов, поскольку сформированы в результате длительной человеческой деятельности, направленной на сохранение и воспроизводство редких растений. Были исследованы окультуренные почвы на территории Ботанических садов г. Москвы - Филиал Ботанического сада МГУ «Аптекарский огород» (проспект Мира) и Ботанический сад МГУ (Ленинские горы).

Распределение показателей общей численности бактерий в основных генетических горизонтах культурозема и рекреазема на территории Филиала Ботанического сада МГУ «Аптекарский огород» характеризовалось высокими значениями общей численности бактерий и культивируемых бактерий сапротрофного комплекса. Вниз по профилю наблюдалось незначительное уменьшение численности бактерий, высокая численность бактерий зафиксирована не только в верхнем, но также и в погребенных гумусовых горизонтах. Это отличает исследованные почвы как от сильнозагрязненных городских почв, так и от природных ненарушенных почв той же природной зоны, где наблюдается довольно резкое падение вниз по профилю показателей общей численности бактерий, численности и родового разнообразия культивируемых сапротрофных бактерий.

Для исследованных почв Ботанического сада МГУ «Аптекарский огород» характерно активное развитие целлюлозоразрушающих бактерий по всему профилю, что связано, видимо, с хорошим состоянием растительности ботанического сада и отражает активно идущие процессы разложения органического вещества, поступающего в почве. Важной особенностью исследованных образцов рекреазема и культурозема являлось высокое родовое разнообразие бактерий по всему исследованному профилю. В группу доминантов и субдоминантов по всему профилю исследованных почв входили, как правило, представители родов Myxococcus и Bacillus. Отмечено высокое содержание рода Arthrobacter, часто выделялись представители рода Rhodococcus, известные устойчивостью к различным типам загрязнения, причем они проникали даже в нижние горизонты профиля. Изученные поч- 
вы характеризовались высоким содержанием артробактерий (род Arthrobacter) и актиномицетов (род Streptomyces), тяготеющих к нейтральным и щелочным значениям рН почвы. Обильное развитие миксобактерий (род Myxococcus) наблюдалось также по всему профилю.

Исследованные почвы Ботанического сада характеризовались также высоким видовым разнообразием представителей рода Bacillus. Постоянно из всех исследованных горизонтов выделялись представители видов B. subtilis, B. cereus, B. megaterium, реже выделялись B. pumilis, B. sphaericus, B. macerans, B. polymyxa. Ранее в литературе отмечалось значительное содержание споровых бактерий в городских почвах [Раппопорт и др., 2001]. Следует отметить, что в исследованных почвах в значительном количестве, помимо эвритопного вида $B$. subtilis, обнаружены также B. cereus (типичный обитатель дерново-подзолистых почв) и B. megaterium (выделяющийся, как правило, из более южных пахотных почв). Специфической особенностью исследованных почв ботанических садов является частое обнаружение бактерий рода Azotobacter, представленного двумя видами - Azotobacter chroococcum (обычно встречающийся в хорошо окультуренных дерновоподзолистых почв) и Azotobacter nigricans (выделяющийся, как правило, из более южных почв). Широкое распространение рода Azotobacter в некоторых почвах города Москвы было выявлено ранее, однако это касалось вида Azotobacter chroococcum [Почва, город, экология, 1991], нами же был впервые в значительных количествах выделен Azotobacter nigricans, имеющий характерную черную пигментацию, ранее выделявшийся только из южных почв [Звягинцев и др., 2005].

Высокое разнообразие бактериальных комплексов в почвах ботанических садов, находящихся в условиях длительной земледельческой практики, в том числе и в погребенных горизонтах рекреазема и культурозема, может рассматриваться как одна из дополнительных функций ботанических садов, осуществляющих защиту не только растений, но и бактериального генофонда [Раппопорт и др., 2001].

В течение трех лет (2012-2014 гг.) нами изучалась биологическая активность верхнего горизонта почв (технодерново-подзолистые, серогумусовая и технозем) на территории БС МГУ (Ленинские горы). Следует отметить, что общие закономерности изменения показателей численности бактерий, длины грибного мицелия и биомассы отдельных групп почвенных микроорганизмов были одинаковы в разные годы исследования. Чис- 
ленность бактерий варьировала от 1.5 до 3.4 млрд. клеток в 1 г почвы. При этом показатели численности бактерий в технодерново-подзолистых почвах были немного выше, чем в серогумусовых на техногенных отложениях, минимальный показатель численности был зафиксирован в техноземе (рекреаземе). Полученные показатели численности бактерий соответствуют средней (технодерново-подзолистая, серогумусовая) и бедной (технозем (рекреазем)) степени обогащенности почвы бактериями по шкале Д.Г. Звягинцева [Методы почвенной микробиологии и биохимии, 1991].

Длина грибного мицелия в исследованных образцах почв составляла от 200 до 1230 м в 1 г почвы. Максимальные показатели длины грибного мицелия зафиксированы в технодерново-подзолистых почвах под лиственницей и кленом, минимальные - под орехом и газоном. Полученные показатели длины грибного мицелия соответствуют богатой (почвы дендрария) и средней (под газоном) степени обогащенности почвы микромицетами, однако, так же, как и показатели численности бактерий меньше, чем в верхнем горизонте ненарушенных дерново-подзолистых почв той же природной зоны. Общая микробная биомасса (бактерии + грибы) составляла от 893 до 5026 мкг в 1 г почвы. Максимальные показатели грибной биомассы зафиксированы в образцах технодерново-подзолистой почвы под лиственницей и серогумусовой почвы под елью, минимальные - в техноземе (рекреаземе) под газоном, что, вероятно, связано с разной мощностью и степенью разложения подстилки на поверхности почвы. Содержание прокариотной (бактериальной) биомассы было максимальным в техноземе под газоном, минимальным - в образцах почвы под лиственницей и елью, то есть в почвах с подстилкой мощнее 1 см, где отмечались максимальные величины длины грибного мицелия [Розанова и др., 2016].

В почвах БС МГУ (Ленинские горы) была также определена ферментативная активность верхних горизонтов почв. Ферментативную активность почвы принято рассматривать как совокупность процессов, катализируемых внеклеточными (иммобилизованными на почвенных частицах и стабилизированными в почвенном растворе) и внутриклеточными ферментами почвенных микроорганизмов. Это один из показателей биологической активности почв, характеризующий потенциальную способность системы сохранять гомеостаз [Звягинцев, 1987]. Чаще всего в почве изучаются ферменты классов оксидоредуктаз и гидролаз. Оксидоредуктазы катализируют окислительно-восстановительные реакции, являясь основ- 
ным звеном в процессе синтеза гумусовых веществ в почве. Гидролазы осуществляют реакцию гидролиза разнообразных сложных органических соединений. Они широко распространены в почвах и играют важную роль в обогащении их подвижными и доступными для растений и микроорганизмов питательными веществами, разрушая высокомолекулярные соединения. В процессе работы была определена активность оксидоредуктаз (каталаза и дегидрогеназа) и гидролаз (инвертаза и уреаза). Показатели активности каталазы в технодерново-подзолистых почвах были немного выше, чем в серогумусовых почвах, и соответствуют средней обогащенности по шкале Д.Г. Звягинцева [Методы почвенной микробиологии и биохимии, 1991]. Еще меньше значения активности фермента, зафиксированные в техноземе, бедном каталазой. Активность дегидрогеназы в почвах дендрария в целом больше, чем в техноземе, но и там по степени обогащенности ферментом почва очень бедная. То же можно сказать и про активность инвертазы. Практически для всех исследованных групп ферментов зафиксирована активность ниже, чем обычно регистрируется в верхнем горизонте ненарушенных дерново-подзолистых почв [Методы почвенной микробиологии и биохимии, 1991]. Показатели активности уреазы в технодерново-подзолистой почве, серогумусовой почве и техноземе (рекреаземе) соответствуют средней обогащенности почвы уреазой, что сравнимо с показателями, которые обычно регистрируются в верхнем горизонте дерново-подзолистых почв южной тайги. Полученные данные об относительно высокой активности уреазы в исследуемых почвах могут быть объяснены имеющейся рекреационной нагрузкой на почву вследствие посещений БС человеком и животными. Низкую обогащенность почв ферментами (оксидоредуктазами) следует рассматривать как свидетельство уменьшения интенсивности процессов синтеза гумусовых веществ, а высокую активность уреазы - в пользу обогащенности городских почв органическими азотсодержащими загрязнителями (мочевиной, аминокислотами, пептидами, белками, аминами и т. п.).

Применение газохроматографических методов исследования дает возможность изучить интенсивность важных почвенных процессов микробиологической природы, связанных с выделением парниковах газов в атмосферу. Эмиссия диоксида углерода - актуальная и потенциальная была выше в почвах дендрария (БС МГУ), ниже в техноземе, что может быть связано с высоким содержанием грибной биомассы в почве. Содержание микробной 
биомассы (активно выделяющей диоксид углерода) более или менее близко во всех исследованных почвах, но эти показатели ниже, чем в природных ненарушенных почвах той же природной зоны. Те же закономерности выявлены при изучении для процесса денитрификации. Азотфиксация (процесс строго бактериальный) наиболее интенсивно протекала в техноземе, более низкие значения зафиксированы в почвах под древесной растительностью. Эмиссия метана (также бактериальный процесс) интенсивнее протекает в почвах дендрария, ниже показатели для технозема (рекреазема). Возможно, это связано с большей влажностью почв дендрария.

Результаты изучения интегральных (численности, жизнеспособности бактерий, содержания фильтрующихся форм бактерий) и дифференциальных (структуры сапротрофного бактериального комплекса) характеристик микробного сообщества городских почв свидетельствуют о значительном разнообразии бактериального населения городских почв. В урбаноземах, загрязненных тяжелыми металлами и нефтепродуктами, зафиксировано уменьшение содержания жизнеспособных клеток бактерий и увеличение содержания фильтрующихся форм бактерий, представленных как вегетативными, так и покоящимися (цистоподобными) формами. Показатели численности бактериофагов, определенные с помощью прямого микроскопического метода (окраска красителем SYBR Green) довольно высоки и сравнимы, а иногда и выше, чем численность бактерий в этих почвах. Численность бактериофагов в исследованных городских почвах была выше, чем численность в природных ненарушенных почвах той же природной зоны, что свидетельствует о высокой жизнеспособности бактериофагов в условиях загрязнения почвы тяжелыми металлами и нефтепродуктами. Значительное морфологическое разнообразие бактерифагов также свидетельствует об их высокой устойчивости к загрязнению почвы тяжелыми металлами и нефтепродуктами.

В городских загрязненных почвах существенно изменяется таксономическая структура сапротрофных бактериальных комплексов в сторону увеличения представленности бактериальных таксонов, не свойственных природным ненарушенным почвам. Бактериальные комплексы загрязненных городских почв отличаются от сообществ ненарушенных зональных почв соотношением таксонов и спектром потенциальных доминантов. При загрязнении нефтью и полихлорбифенилами потенциальными доминантами становятся родококки (род Rhodococcus), 
комплексном хозяйственно-бытовом загрязнении - энтеробактерии (роды Escherichia, Enterobacter, Klebsiella), при загрязнении цементной пылью - род Arthrobacter. В городских загрязненных почвах прослеживается тенденция накопления опасных для человека бактерий - потенциально патогенных (роды Escherichia, Enterobacter, Klebsiella, Alcaligenes) и аллергенных (род Rhodococcus, Micrococcus). Почвы, сформированные в условиях длительной земледельческой практики (ботанические сады) характеризуются более высокой численностью и иным профильным распределением бактерий, а также структурой сапротрофного бактериального комплекса, чем фоновые почвы. Сапротрофный бактериальный комплекс почв городских ботанических садов (рекреаземов и культуроземов) проявляет черты сходства с почвами более южных регионов. Очевидно, что почвы городских ботанических садов требуют особо бережного отношения к ним, поскольку они выполняют функцию сохранения и поддержания микробного разнообразия, особенно в погребенных горизонтах.

Сравнение показателей ферментативной активности почв (активность окислительно-восстановительных и гидролитических ферментов) и активности процессов трансформации углерода и азота в городских почвах (азотфиксация, денитрификация, эмиссия диоксида углерода и метана) свидетельствуют о том, что напряженность микробиологических процессов, за редким исключением (азотфиксация), уменьшается в ряду: технодерново-подзолистая почва - серогумусовая почва - технозем (рекреазем). В целом, практически все показатели ферментативной активности ниже, чем в природных почвах южной тайги. Низкую обогащенность оксидоредуктазами следует, видимо, рассматривать как свидетельство уменьшения интенсивности процессов синтеза гумусовых веществ. Высокая обогащенность почв уреазой отражает высокое содержание в городских почвах органических азотсодержащих загрязнителей (мочевина, аминокислоты, пептиды, белки, амины и т. п.).

Итак, в урбаноземах, загрязненных тяжелыми металлами и нефтепродуктами, зафиксировано уменьшение содержания жизнеспособных клеток бактерий и увеличение содержания фильтрующихся форм бактерий, представленных как вегетативными, так и покоящимися (цистоподобными) формами, увеличение численности бактериофагов по сравнению с природными ненарушенными почвами той же природной зоны. Существенно изменяется таксономическая структура сапротрофных бак- 
териальных комплексов в сторону увеличения представленности бактериальных таксонов, не свойственных природным ненарушенным почвам.

Городские почвы, сформированные в условиях длительной земледельческой практики (ботанические сады), характеризуются более высокой численностью, иным профильным распределением бактерий и структурой сапротрофного бактериального комплекса, чем фоновые почвы. Сравнение различных показателей биологической активности свидетельствуют о том, что напряженность микробиологических процессов, за редким исключением (азотфиксация), уменьшается в ряду: технодерновоподзолистая (рекреазем, Technic Retisol) - серогумусовая (Urbic Technosol (gray-humus)) - рекреазем (Urbic Technosol (recreasem)) - тезнозем (Urbic Technosol (technozem)).

Изучение активности и разнообразия микробных сообществ городских почв представляют значительный интерес не только с точки зрения фундаментальной науки, но и в практическом отношении, вследствие важной роли микроорганизмов в создании и поддержании устойчивости городских экосистем, выполнении ими важных экологических функций почвы. Выявление индикаторных по отношению к разным типам загрязнения таксонов микроорганизмов также имеет важное практическое значение. Использование свойств «ключевых» популяций важно для поиска микроорганизмов, которые могут служить объектами биотехнологии. Понимание закономерностей функционирования микробных сообществ в городских почвах, специфики их функционирования в почвах загрязненных тяжелыми металлами, нефтепродуктами и прочими органическими загрязнителями, а также в почвах городских ботанических садов и парков, позволит наметить подходы к управлению важными популяциями почвенных организмов для сохранения «здоровья» почвы и благополучного проживания населения в городских экосистемах.

\section{Литература}

1. Дуда В.И., Сузина Н.Е., Поливцева В.Н., Боронин А.М. Ультрамикробактерии: становление концепции и вклад ультрамикробактерий в биологию // Микробиология. 2012. Т. 81. № 4. С. 415 - 427.

2. Звягинцев Д.Г. Почва и микроорганизмы. М.: Изд-во Моск. ун-та, 1987. $256 \mathrm{c}$.

3. Звягинцев Д.Г., Бабьева И.П., Зенова Г.М. Биология почв: Учебник. М.: 2005. 445c. 
4. Кудинова А.Г., Лысак Л.В., Лапыгина Е.В., Соина В.С., Мергелов Н.С. Разнообразие и жизнеспособность прокариот в примитивных почвах оазиса Ларсеманн (Восточная Антарктида) // Известия РАН. Серия биологическая, 2015, том 42, № 2. С.127 - 133.

5. Лапыгина Е.В., Лысак Л.В., Москвина М.И., Звягинцев Д.Г. Численность вирусов в аллювиально-дерновой почве (метод прямой эпифлуоресцентной микроскопии)// Микробиология, 2016, т. 85, № 6. С 748 - 751.

6. Лысак Л.В., Добровольская Т.Г., Скворцова И.Н. Методы оценки бактериального разнообразия и идентификации почвенных бактерий. 2003.М.: МАКС Пресс, 120 с.

7. Лысак Л.В., Лапыгина Е.В., Конова И.А., Звягинцев Д.Г. Численность и таксономический состав ультрамикробактерий в почвах // Микробиология, 2010, том 79, № 3. С. $428-432$.

8. Лысак Л.В., Лапыгина Е.В., Конова И.А., Звягинцев Д.Г. Численность и таксономический состав наноформ бактерий в некоторых почвах России // Почвоведение, 2010, № 7. С. 819 - 824.

9. Лысак Л.В., Лапыгина Е.В. Разнообразие бактериальных сообществ городских почв // Почвоведение, 2018, № 9. С. 1108 - 1114.

10. Методы почвенной микробиологии и биохимии/ Отв. ред. Д.Г. Звягинцев. М.: Изд-во МГУ, 1991,303 с.

11. Почва, город, экология. / Под общей редакцией академика РАН Г.В. Добровольского. М.: Изд-во МГУ, 1997, 310 с.

12. Раппопорт А.В., Лысак Л.В., Прокофьева Т.В., Строганова М.Н. Особенности почв филиала Ботанического сада МГУ//Вестник Моск. Унта. Сер. 17. Почвоведение, 2001, № 3. С. 26 - 32.

13. Розанова М.С., Прокофьева Т.В., Лысак Л.В., Рахлеева А.А. Органическое вещество почв Ботанического сада МГУ имени М.В. Ломоносова на Ленинских горах // Почвоведение, 2016, № 9. С.1079 - 1092.

14. Соина В.С., Лысак Л.В., Конова И.А., Лапыгина Е.В., Звягинцев Д.Г. Электронно-микроскопическое исследование наноформ бактерий в почвах и подпочвенных отложениях // Почвоведение, 2012, № 11. С. 1188 - 1198.

15. Степанов А.Л. Микробная трансформация парниковых газов в почвах. М.: ГЕОС. 2011. 192 с.

16. Строганова М.Н., Раппопорт А.В. Специфика антропогенных почв ботанических садов крупных городов южной тайги // Почвоведение, № 9, 2005. С. 1094 - 1101. 